○第15回日本ゴム協会賞受賞者報告○

\title{
EPDM/樹脂アロイの開発
}

$\begin{array}{ccc}\text { 三井化学株式会社 } & \text { 川崎 } & \text { 雅昭 } \\ & \text { 仲濱 } & \text { 秀斉 } \\ & \text { 東條 } & \text { 哲夫 } \\ & \text { 三島 } & \text { 孝 }\end{array}$

この度は, 日本ゴム協会賞受賞の栄に浴し，光栄に 存じます。これも，本開発にあたり種々ご教示頂きま した多くの方々のおかげと，関係者一同厚く御礼を申 し上げます，以下，本開発の概要について説明致しま す.

\section{1. 開発の背景}

エチレン・プロピレン・ジエン共重合体(EPDM) と 樹脂とのアロイの中で, 主成分がポリプロピレン $(\mathrm{PP})$ であるアロイは，耐衝撃性PP，熱可塑性エラストマ 一として用いられていますが，加硫ゴム原料としての 利用は，ポリエチレン $(\mathrm{PE})$ が一部使用されているに すぎませんでした。これは，ベール状のEPDMと少 量のペレット状樹脂を均一に混練することが工業的に 困難であったためと考えられます。本関係者らは，ま ず， $\mathrm{EPDM} /$ 樹脂アロイを加硫ゴム原料として工業的 に容易に利用できるようにすること，また，得られた アロイの特徴を見いだし，それを活かすことを目標に 開発を開始しました。

\section{2. 技術の内容}

$\mathrm{EPDM} /$ 樹脂アロイには，EPDM と低密度 PEのよ うな相容型, EPDM とPPのような非相容型のものが あります。

\section{1 ) 相容型EPDM/樹脂(PE)アロイ}

EPDMにPEをアロイ化することで，加工性，加硫 ゴム硬度と伸びのバランスをとることができますが, $\mathrm{PE}$ の未潰れ不良の懸念がありました。 EPDM/PEア ロイを提供することで, その懸念が払拭されました。

2 ) 非相容型EPDM/樹脂(PP)アロイ

EPDMを主成分とするEPDM/PPアロイは，混練
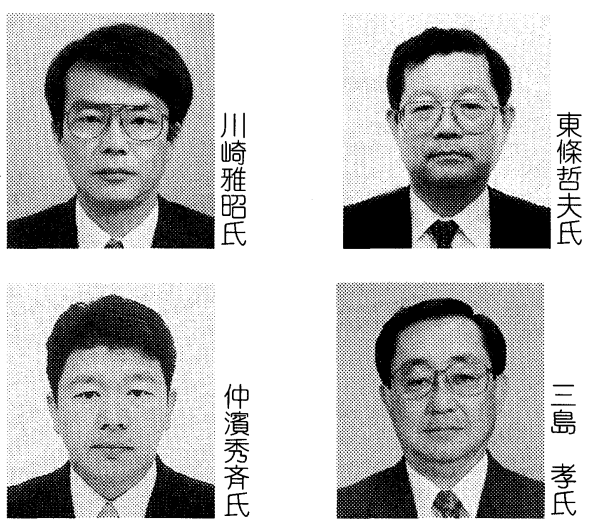

の問題からほとんど利用されていませんでした.この アロイは，海相である EPDM中に, PPが粒子径 $1 \mu$ $\mathrm{m}$ 前後に分散しています。この分散したPPは“ポリ マー充てん材”，と見なすことができ，このポリマー充 てん材は, ゴムの加工工程で融ける, 軽い, 電気絶縁 性が高いなどの特徴を有しています。こうした特徴の ためEPDM/PPアロイは新たな性能を発揮することを 見いだしました。

\section{(2-1) 剛性と加工性}

$\mathrm{EPDM} / \mathrm{PP}$ アイを加硫ゴムとして用いる場合, PPは “融ける充てん材”として㗢くため，ゴム弾性 を維持しながら，剛性を高くできますが，加硫成形時 融けるため, 剛性の高いコンパウンドでありながら流 動性, 発泡性が向上します. 特に, 剛性が高く, 高発 泡で，しかもゴム弾性の必要なスポンジ材料として好 適な材料となると考えられます。

\section{(2-2) 形状記憶性}

EPDM/PPアロイは，“形状記憶ゴム”となること を見いだしました。

この現象を利用し, ゴム弾性に優れた収縮チューブ, 曲管の製造工程簡略化が可能であることを提案しまし た。

\section{3. まとめ}

$\mathrm{EPDM} /$ 樹脂アロイを，加硫ゴム原料として利用す るという新たな分野を開拓できたのは, 三井化学(株)の 関係者の皆様, ならびに，我々の話に耳を傾けていた だいたお客様方のおかげと心から感謝, 御礼を申し上 げます. 今後も, お客様方のお役に立つべく, 研究開 発に精進いたしますので，よろしくお願いいたします。 